
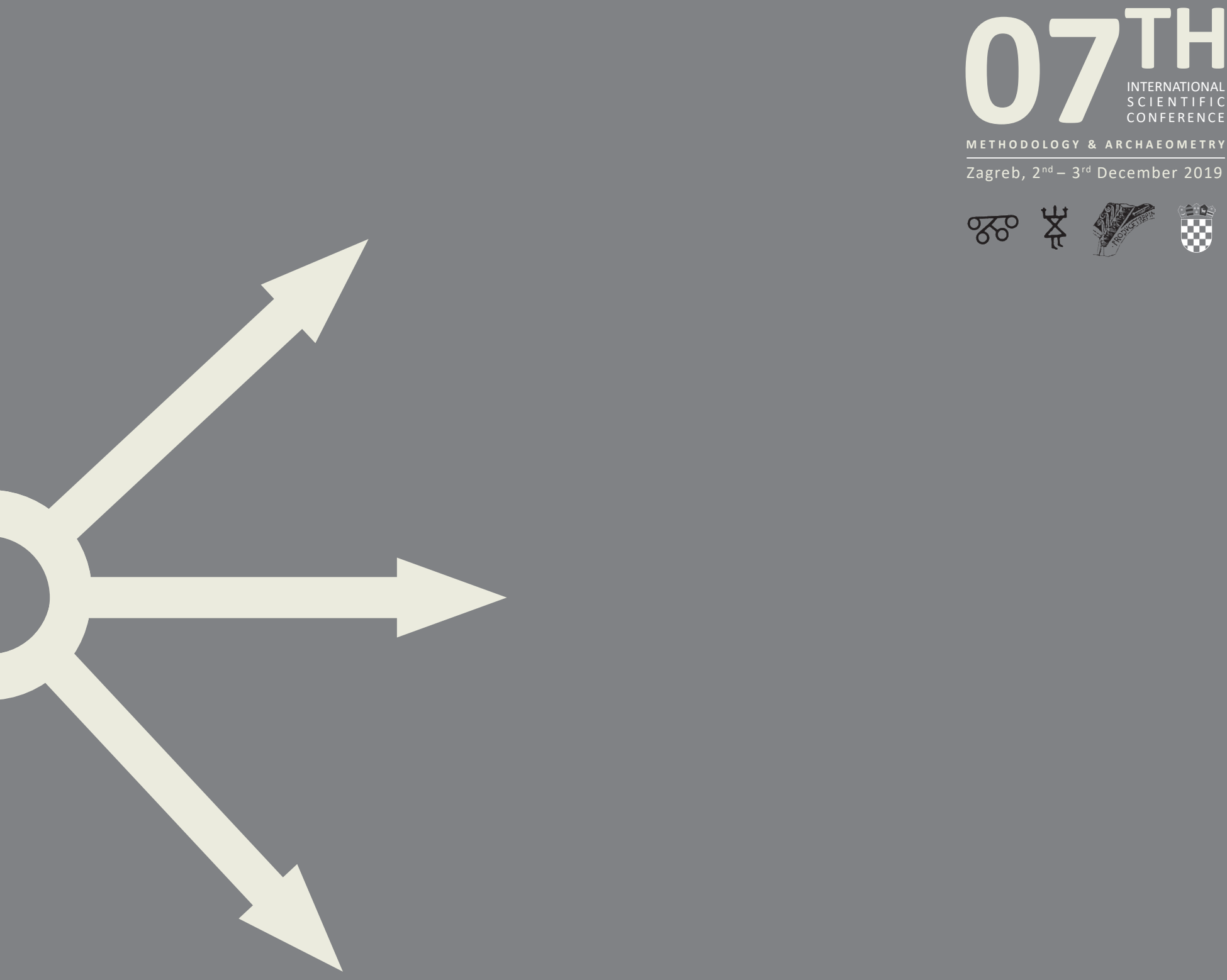
\%ㅇㅇ 岗

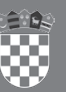
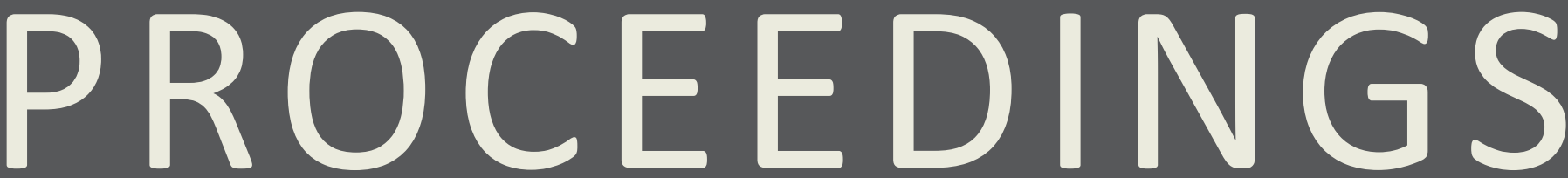

FROM THE $7^{\text {TH }}$ SCIENTIFIC CONFERENCE METHODOLOGY AND ARCHAEOMETRY 


\section{IMPRESSUM}

PUBLISHER

Faculty of Humanities and Social Sciences, University of Zagreb

FOR THE PUBLISHER

Miljenko Šimpraga

EDITOR

Ina Miloglav

Faculty of Humanities and Social Sciences, University of Zagreb

EDITORIAL BOARD

Predrag Novaković

Faculty of Arts, University of Ljubljana, Slovenia

Dimitrij Mlekuž

Faculty of Arts, University of Ljubljana

\& Centre for preventive archaeology, Ljubljana, Slovenia

Michela Spataro

The British Museum, London, United Kingdom

Duska Urem-Kotsou

Democritus University of Thrace, Komotini, Greece

Jasna Vuković

Faculty of Philosophy, University of Belgrade, Serbia

Rajna Šošić Klindžić

Faculty of Humanities and Social Sciences, University of Zagreb, Croatia

Jacqueline Balen

Archaeological Museum in Zagreb, Croatia

DESIGN \& DTP

Srećko Škrinjarić

All papers were reviewed in the peer review process in which the identity of both reviewers and authors, as well as their institutions, are respectfully concealed from both parties.

DOI

https://doi.org/10.17234/METARH.2020

ISSN 2718-2916

Faculty of Humanities and Social Sciences of the University of Zagreb

URL

https://openbooks.ffzg.unizg.hr/index.php/FFpress/catalog/series/MetArh http://www.ffzg.unizg.hr/metarh/

Publishing of this e-book is supported by

Ministry of Science and Education of the Republic of Croatia any medium or format, as long as they give appropriate credit, provide a link to the license, and indicate if changes were made. The content of this publication may not be used for commercial purposes. If the publication is remixed, transformed, or built 

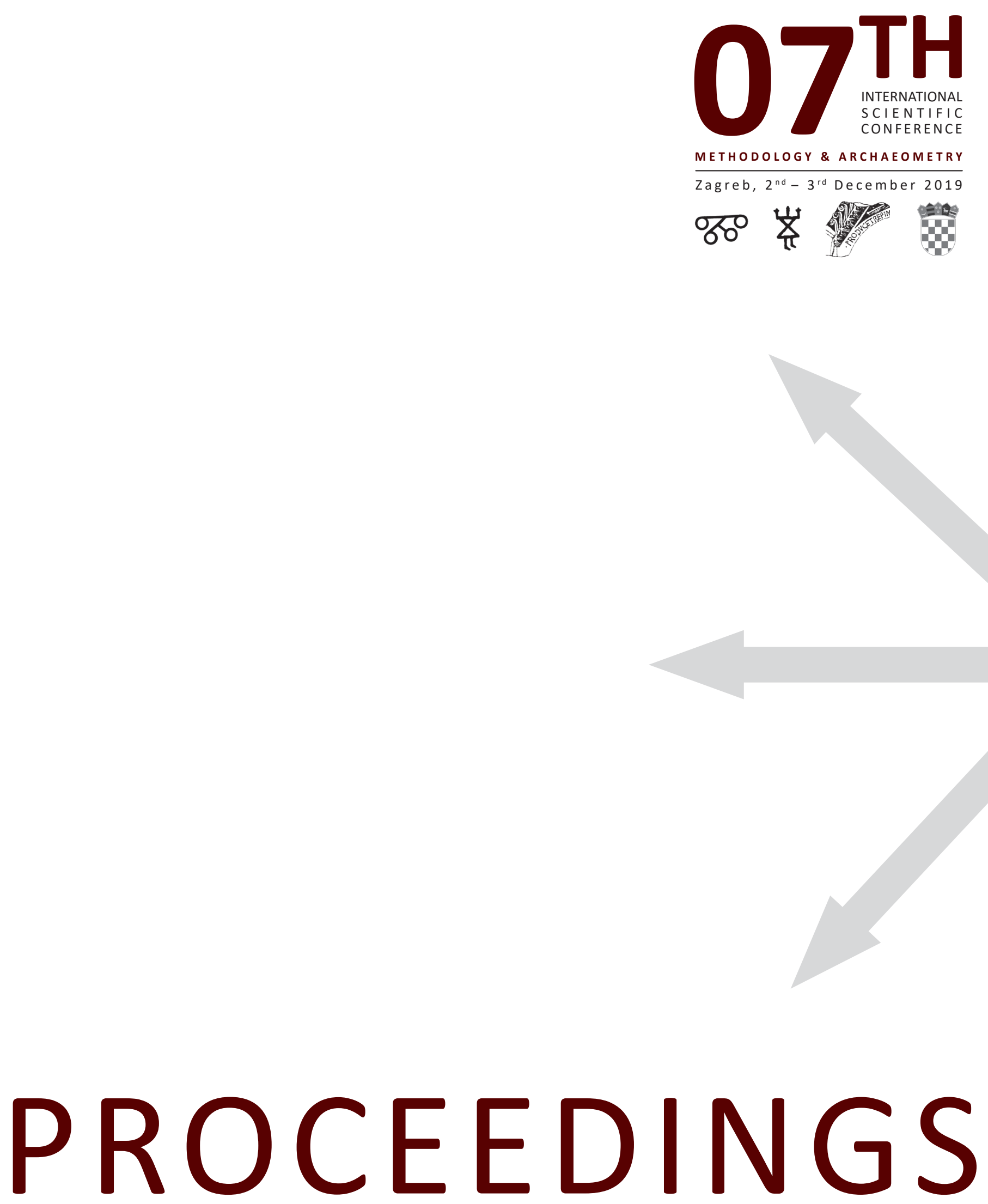

FROM THE $7^{\text {TH }}$ SCIENTIFIC CONFERENCE METHODOLOGY AND ARCHAEOMETRY 


\section{Content}

Ina Miloglav

Preface

Tamara Leskovar

09 Laboratory-based research on the changes caused to the in situ preserved archaeological remains by the heavy equipment compaction

Cornelius Meyer, Saša Kovačević, Daria Ložniak Dizdar, Mario Gavranović, Rajna Šošić-Klindžić, Tomislav Hršak, Marko Dizdar, Hrvoje Vulić, Boris Kratofil

Patterns everywhere: Geophysical prospection strategies at archaeological sites in Northern and Eastern Croatia

Domagoj Tončinić, Vinka Matijević, Miroslav Vuković

Image-based modeling approach in documenting Early Christian memorial chapel in Velić, Croatia

Esmeralda Agolli

A discussion on the theoretical and methodological ramifications of classification and typology of archaeological material: a Perspective from the Late Prehistoric Pottery (Albania)

Katarina Šprem

All aboard! Quarries and transport in Roman Istria 


\title{
All aboard! Quarries and transport in Roman Istria
}

\author{
Katarina Šprem
}

https://doi.org/10.17234/METARH.2020.06

Katarina Šprem Centre for Interdisciplinary Research in Landscape Archaeology

Faculty of Humanities Juraj Dobrila University of Pula

1 Matetić Ronjgov

HR-52100 Pula katarina.sprem@unipu.hr

The great need for stone as a building material in Roman Istria is attested by a large number of quarries along the Istrian coast, and several in the interior. The more or less high-quality limestone from these quarries could have been used for the building of many villae rusticae scattered across the peninsula, or perhaps even for further distribution. In that regard, Roman Istria was connected by a system of roads, the precise heading of which we are today still uncertain. The road connecting Aquilea and Pola was called Via Flavia, and several authors suggest that a road of the same name connected Pola to Tarsatica. Nevertheless, a much cheaper system of transportation was by sea or river, and the Istrian coast is rich with many bays or coves that could have been useful to Roman sailors as safe havens or trading ports.

Keywords: Istria, Antiquity, stone, quarries, roads, holloways, ports

\section{Introduction}

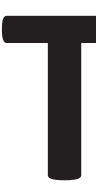

he Roman history of Istria began with the war in $178-177$ BC. Infamous pirates, the Histri came under Rome's notice for disturbing the normal flow of sea traffic and trade which resulted in the first Roman-Histri war of 221 BC (Matijašić 1998: 32). Having defeated the Histri, Rome wasn't planning on subduing the whole of Istria, but that became nec- essary not long after. The Histrian king Epulo called to arms which resulted in another conflict in 178 BC. After having defeated the Histri, Rome pacified the northern Adriatic (Matijašić 1991: 236-239; Matijašić 2017: 381). Then, after several centuries, around $45 \mathrm{BC}$, the colonies Pola and Parentium were established and romanization of the peninsula began in earnest. The colonies were es- 


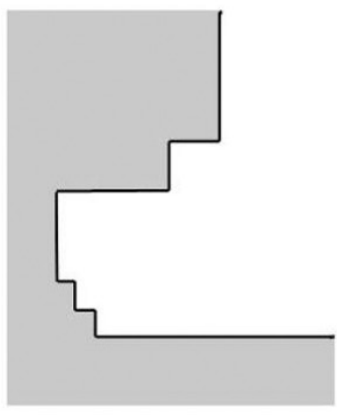

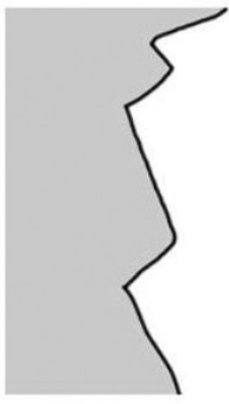

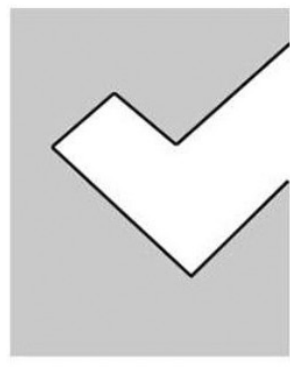

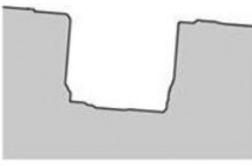

4

Figure 1. Examples of rectangular layouts of Roman quarries in Dalmatia, Croatia: 1 - Dugi otok, Padrare; 2 - Trogir, Sv. Ilija; 3 - Korčula, Kamenjak; 4-Kamenjak near Molat (after: Parica 2014a: 141).

tablished as a means of giving land along the western coast of the peninsula to the veterans and other Roman citizens, and the Histri were eventually integrated into the Roman state (Matijašić 2017: 383). Roman rural estates also started developing. There are now more than 300 Roman villae rusticae known across the Istrian peninsula, mostly along the coast and withing a narrow strip from it, on the territories of three different agri: Tergeste, Parentium and Pola (Bulić 2014). Roads were built to better connect the controlled area, for quicker information exchange, but also for military and civilian, economic purposes. This connection system had an effect of improving the Roman economy (Matijašić 2009: 195). On the other hand, a less expensive and faster transportation system was by sea or river, and since Istrian coastline, especially western, is rich in bays or coves, this provided the perfect means for developing a network of seaports. There are 51 bays in Istria with the remains of Roman port facilities visible today (Koncani Uhač 2018: 205-393). From an economical perspective, the Roman ports in Istria can be divided into four main categories: colonial ports, secondary ports (for municipia), villae maritimae ports, and ports related to production centres, notably for olive oil or wine (Koncani Uhač 2018: 145-163).

Good road connectedness influenced the economic growth and one of the important branches of the Roman economy, besides the production of olive oil and wine, was quarrying. There are several known "Roman" quarries today and others are being discovered using the analysis of Airborne Laser Scanning (ALS) data. Most of them are located on the western Istrian coastline, while a small number of them are in the hinterland, but close to the supposed line of the main Roman road.

\section{Roman quarries}

In his dissertation and later work, Parica brought up several characteristics that should distinguish Roman age and Mediaeval exploitation of quarries based on quarries whose elements can be reliably dated (Parica 2014: 76). He states that the basic quarrying tool in Classical Antiquity was a 6-8 kilograms heavy two-spiked hammer which leaves between 15 and 19 striae per metre on the quarry face, as opposed to a lighter Medieval two-spiked hammer which can leave between 20 and 26 striae per metre (Parica 2014: 77). He also argues that the layout of exploited quarries should give us an indication of the period of usage. Roman quarries, he says, mostly have the rectangular layout as a result of systemic exploitation: large quantities of regular stone blocks were exploited at the fastest possible rate (Fig. 1). On the other hand, late Mediaeval and Early Modern quarries demonstrate triangular layouts with a $90^{\circ}$ angle in the deepest part (Parica 2014: 79). This layout was a result of smaller, individual exploitations where several blocks were extracted in a row, forming one side of a triangle and each new segment was extracted from a different side of the triangle (Parica 2014: 79). 
Figure 2. Probable Roman age quarries on the Istrian peninsula (made by: Katarina Šprem).

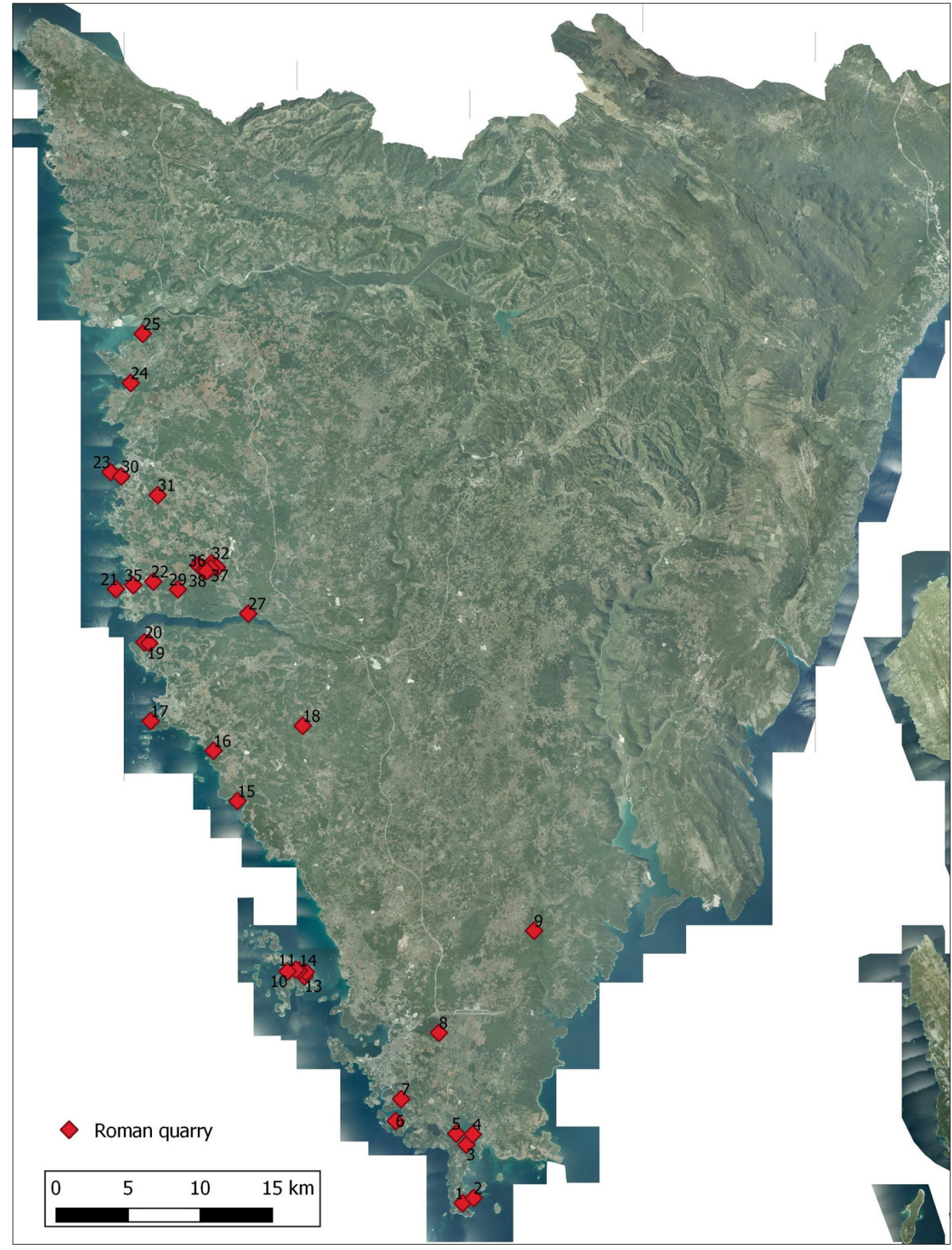

The channel chiselled in order to extract a desired stone block from the rock is called pašarin ${ }^{1}$ in Croatian and this technique came to be used on the Croatian coast and islands after they fell under Roman rule (Parica 2014: 52). Therefore, the pašarin technique, if still seen in a quarry today, presents a sort of a chronological marker for dating the exploitation period of that part of a quarry. Pašarini in combination with other techniques, such as

\footnotetext{
${ }^{1}$ Pašarin or pašarina is a traditional Dalmatian word.
}

wedges or kunjere ${ }^{2}$, and the use of gunpowder, are a sign of a later exploitation period, namely the Middle Ages and the modern era (Parica 2014: 60-61; Parica 2014a: 149). Even though Parica's work is based on quarries in Dalmatia that were exploited in Classical Antiquity and the Middle Ages, there should not be any differences in systems of exploitation between regions of present-day Dalmatia and Istria.

\footnotetext{
2 Kunjere is a traditional Dalmatian word for grooves made for $\mathrm{V}$ shaped wedges used to detach the stone block (Parica 2014: 61; Parica 2014a: 6).
} 


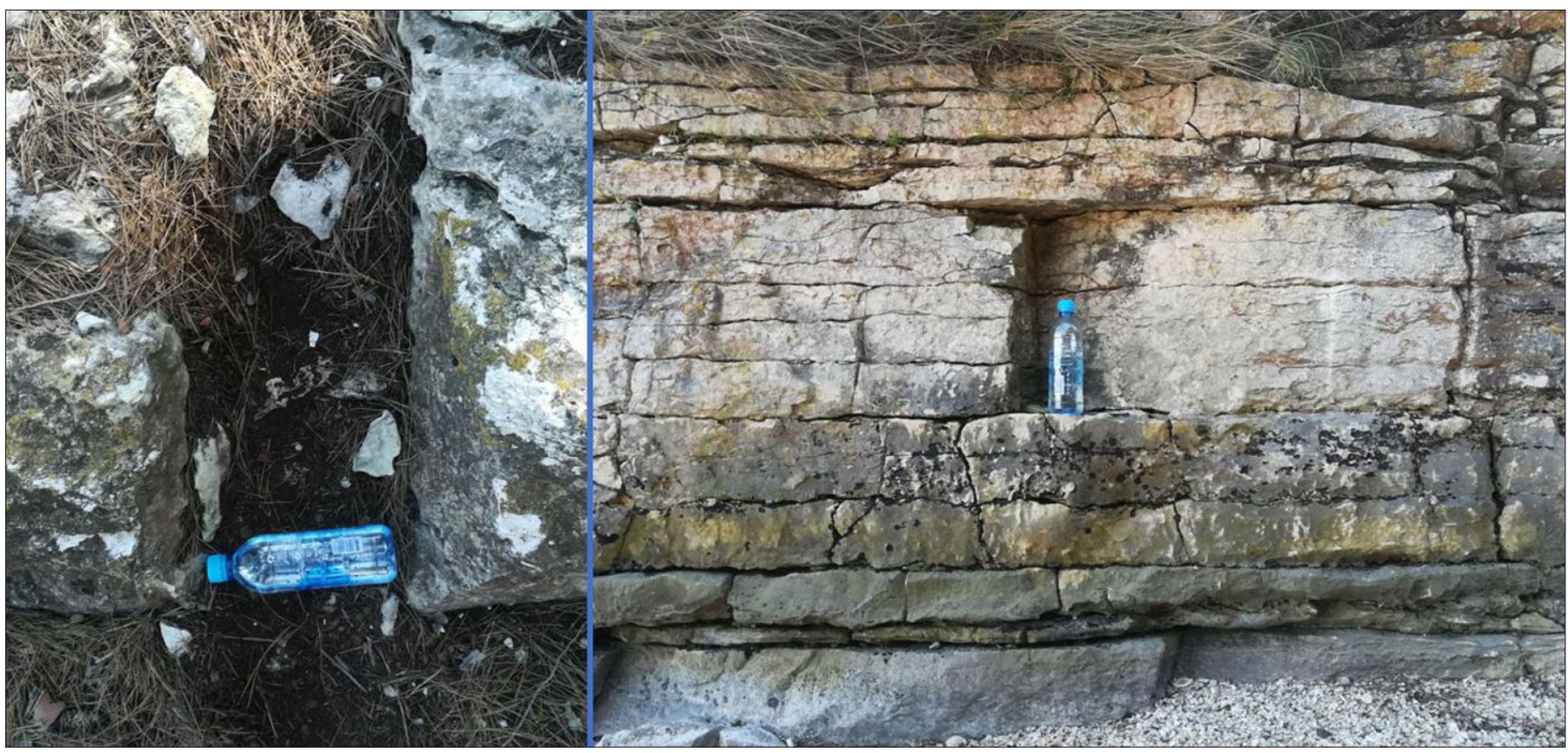

Figure 3. A quarry on Mugli Cape, Premantura: on the left side a pašarin, on the right side platy limestone. Height of the water bottle $21 \mathrm{~cm}$ (made by: Katarina Šprem).

Istrian limestone surface deposits are mostly of Cretaceous age (Miko et al. 2013) and generally of high quality. Therefore, it is not a surprise that it has also been quarried in historical and recent times and is being quarried even today (Šonje 1980; Matijašić 1998; Bratulić and Cotman 2004; Lazzarini 2012). There are several quarries on the western Istrian coastline that are thought to be of Roman age, but several of them have also been quarried in the post-Roman era; therefore, if there were any traces of Roman quarrying, they have been erased by later exploitation (Matijašić 1998: 394). We continue with the description of quarries in Istria that might have been exploited in Antiquity, starting from the south.

On the eastern coast of the Premantura peninsula there is a quarry in the Porto Rosso bay (Fig. 2: 1). There are traces of Roman quarrying in the form of visible pašarini. Also, the southern coast of a nearby small island of Šekovac seems to have been "cut" and the quarry is situated below the sea level which could date the exploitation to Antiquity (Fig. 2: 2). The quarry is of a rectangular shape which would also suggest Roman age; however, a more detailed survey is needed. Next, while walking through the Vižula Archaeological Park we noticed a quarry across the sea on the Mugli cape of the Premantura peninsula (Fig. 3), whose location and appearance are very similar to the small quarry on Šekovac island (Fig. 2: 3). The surface layer is platy limestone between 1 and 2 meters thick, and below is a deposit of architectural stone. Again, the rectangular shape and the location almost below sea level would suggest Roman age. However, the technique of extracting slabs of platy limestone does not leave any traces due to the fact that the rock mass has both horizontal and vertical cracks which naturally separate the slabs without any need for cutting (Parica 2014: 32). Therefore, dating such a quarry is a much more problematic topic. Nevertheless, during the field survey, a fragment of pottery was found, most likely dated to Late Antiquity. Also, the quarry is located on the coastline which is a perfect location for maritime transport. There are several villae rusticae sites nearby which could have been built using stone from this quarry (Bulić 2014).

The Vižula peninsula itself also contains a Roman age quarry (Fig. 2: 4) where "Istrian soft stone" was quarried (Džin and Miholjek 2016). Premanturski školjić island in the northern part of Medulin bay has had its whole southern coast cut by exploitation (Fig 2: 5; Matijašić 1998: 395). Its location is also perfect for maritime transport and it is nearby several villae rusticae sites for which this quarry could have provided the stone.

Two quarries located in Banjole are about 350 meters from the coast (Fig. 2: 6). One at the site of Rupice was 
certainly used during Austro-Hungarian times, but there were several half-worked columns and a woman's head carved in stone found in it forty years ago (Matijašić 1998: 395). The Cavae Romanae quarry near Vinkuran is the place whence the stone for the outer curved wall of the Pola Amphitheatre was extracted (Fig. 2: 7; Crnković 1991: 396). Even today it bears the name Cavae Romanae which could signify its Roman age, or rather a local tradition which reflects its Roman Age use. This quarry is located about 500 meters from Veruda Bay, with a slope of terrain that could have facilitated transport by land to the coast (Šonje 1980: 151). On the eastern edge of Šijana in Pula (Fig. 2: 8) a hill was cut off by a modern quarry, but traces of stone blocks extraction for making sarcophagi were clearly visible at one point (Šonje 1980: 152). Furthermore, on the western slopes of the valley between Marčana and Mutvoran (Fig. 2: 9) there is a large quarry that was probably used in Antiquity as several stone monuments of Pula and Nesactium, the latter of which is nearby were made of such a stone (Matijašić 1998: 398). This should, of course, be verified by further analysis, one of which should be petrography.

The Brijuni islands are also rich in quality stone (Fig. 4). Due to monumental sites, such as the Roman villa in Verige Bay, one can assume the exploitation of stone in Antiquity in several locations: a quarry in Gospina Bay (Val Madonna), the zoo quarry, Čufar quarry, a quarry under Gradina, and Koch quarry, which is also one of the most exploited quarries on the islands (Premužić - Ančić and Gašparović 2017: 80). Most of these quarries were also used in the Middle Ages, but not as intensively as the material from abandoned Roman buildings that was available, which could satisfy the rather modest needs for stone building material (Matijašić 1998: 398).

Moving north along the western Istrian coast, we see traces of stone exploitation at the St. Damijan cape (Fig. 2: 15). It is believed the quarry was not used after Antiq-

Figure 4. Probable Roman age quarries on Veli Brijun Island (made by: Katarina Šprem).

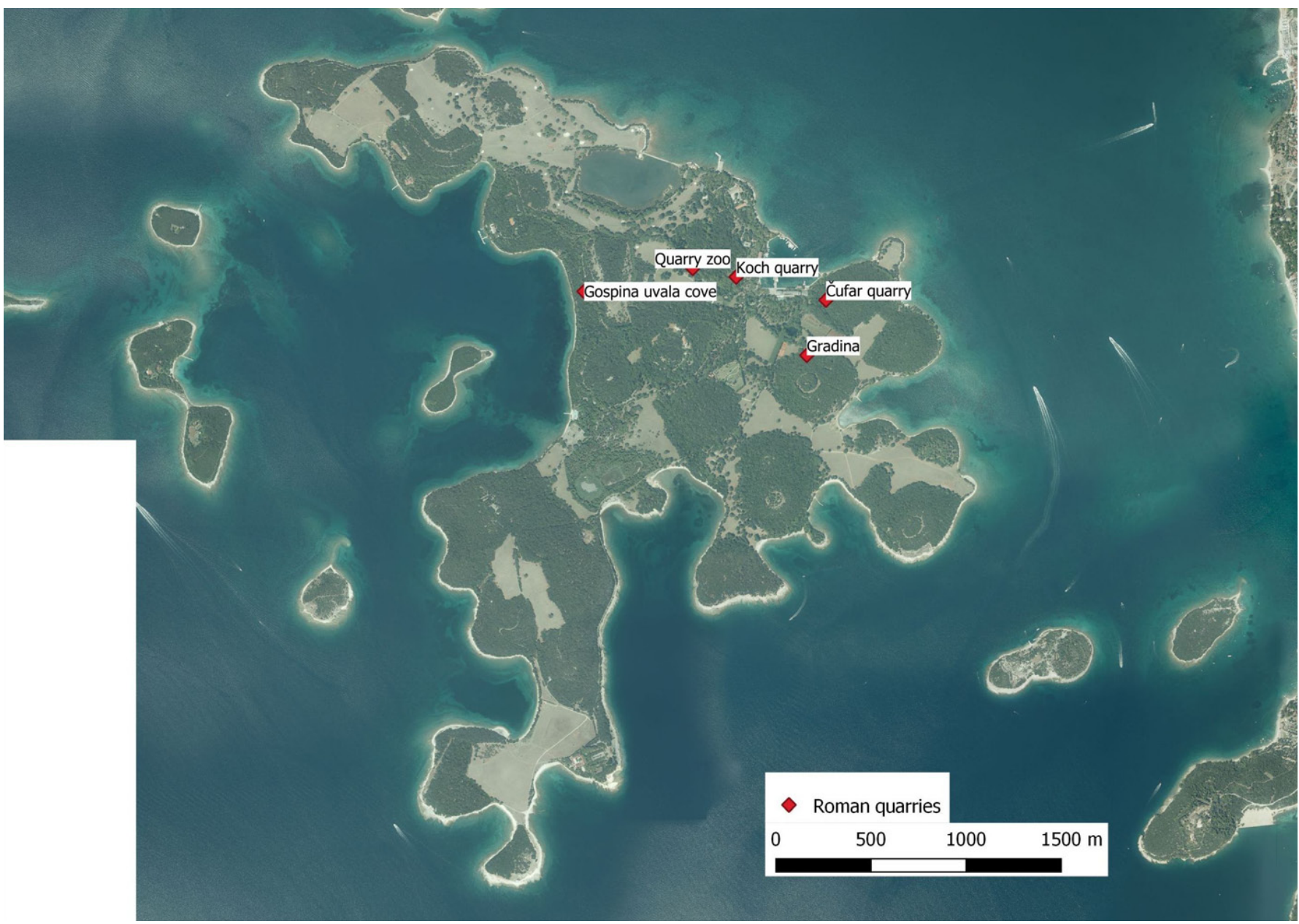


uity. It covers an area of about $300 \mathrm{~m}^{2}$, and it is assumed that about $1000 \mathrm{~m}^{3}$ of stone blocks could have been removed from this place (Matijašić 1998: 396). Like the quarry at the location of Monte delle Arni (Fig. 2: 16), it is in a very convenient location for further transport of stone blocks. At the aforementioned site, Monte delle Arni south of Rovinj, sarcophagi and their unfinished lids have been recorded until recently, which further testifies to their use in Antiquity (Matijašić 1998: 396). Near Rovinj, at Montauro cape (Fig 2: 17), lies the largest quarry in this part of Istria. It is believed it was used in Antiquity due to its convenient location very close to the coast, although there is no direct evidence (Matijašić 1998: 396).

North of Rovinj, there are quarries in Soline Bay and at St. Eufemija cape (Fig. 2: 19, 20). Soline Bay is located at the entrance to the Lim Channel, and traces of Roman exploitation are clearly visible in the quarry. The stone is thinly layered, so only smaller blocks could have been extracted. On the adjacent hill near St. Eufemija cape, there are also traces of stonemasonry visible. According to Šonje, sarcophagi were made from these blocks (Šonje 1980: 152). Near the town of Bale, $6 \mathrm{~km}$ from the coast, there are remains of a small quarry with visible traces of extracted round blocks (Fig 2: 18). Matijašić be- lieves the stone blocks probably weren't carried far from this location and that the extracted stone was used to make monolithic recipients for olive oil plants in a nearby rural villa (Matijašić 1998: 399).

North of the Lim Channel there is a quarry on the islet of St. Juraj near Vrsar (Fig. 2: 21). It shows traces of Roman stone exploitation, but no large blocks of stone were extracted here (Matijašić 1998: 399). The quarry itself is in a very steep location and along a shallow shore, which makes it unsuitable for boarding large stone blocks on vessels (Šonje 1980: 152-153). There is also a quarry on the south side of the hill called Monte Ricco (Gavanov vrh; Fig. 2: 22). A Roman water cistern, as well as a villa rustica, were recorded on the hill itself (Buršić-Matijašić and Matijašić 2016: 17-25), and their interconnection should be examined by petrographic analyses. Furthermore, a part of a hill on which the old town Vrsar lies has been completely cut off and levelled by quarry activity (Fig 2: 35; Fig. 5). Close by, the stone on the island of St. Nikola near Poreč (Fig. 2: 23) is of exceptional quality. The layers of limestone are up to eight meters thick, and there are almost no vertical cracks, so it is considered, along with its convenient location, very suitable for use in Antiquity (Matijašić 1998: 399). In addition,

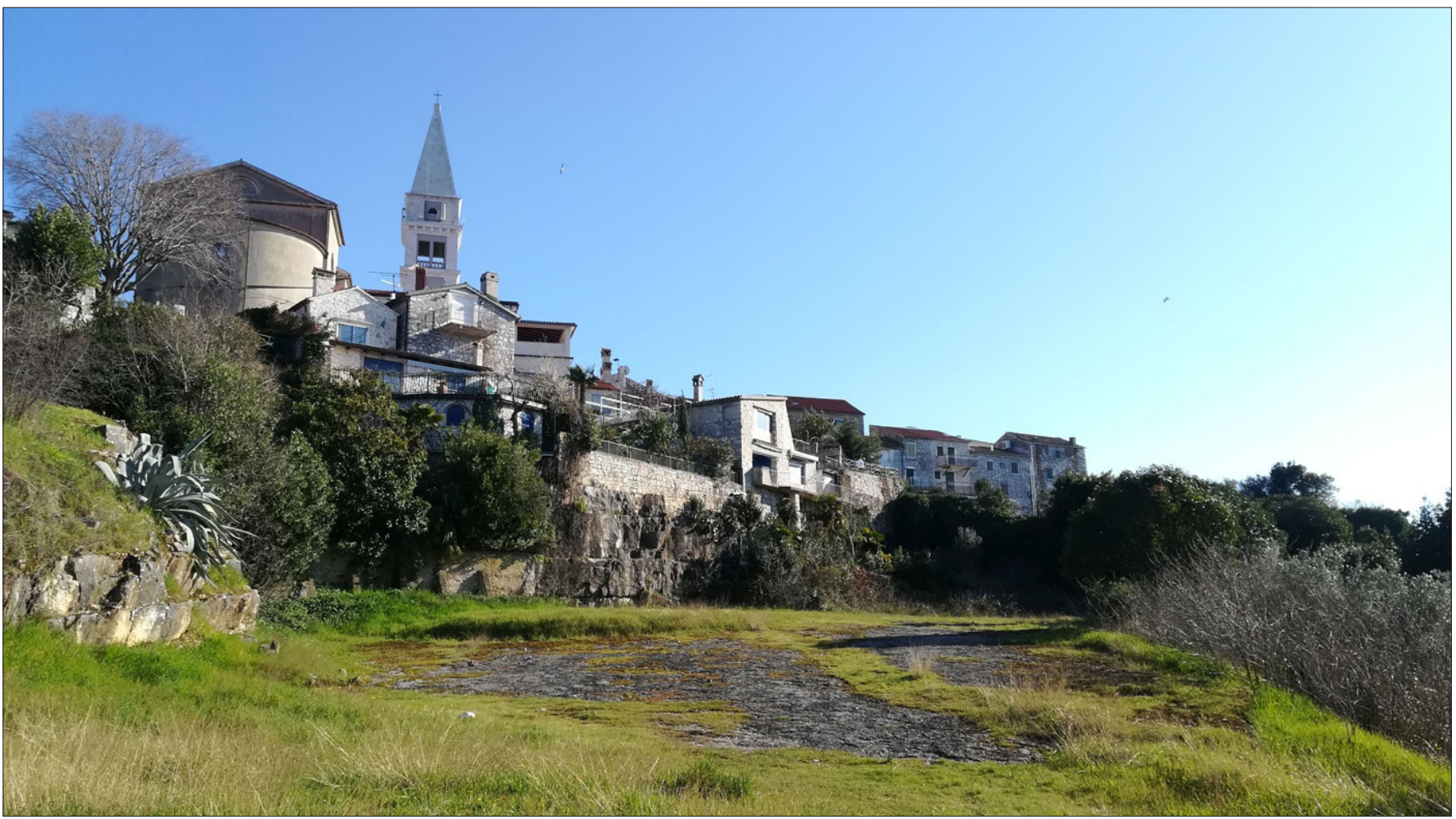




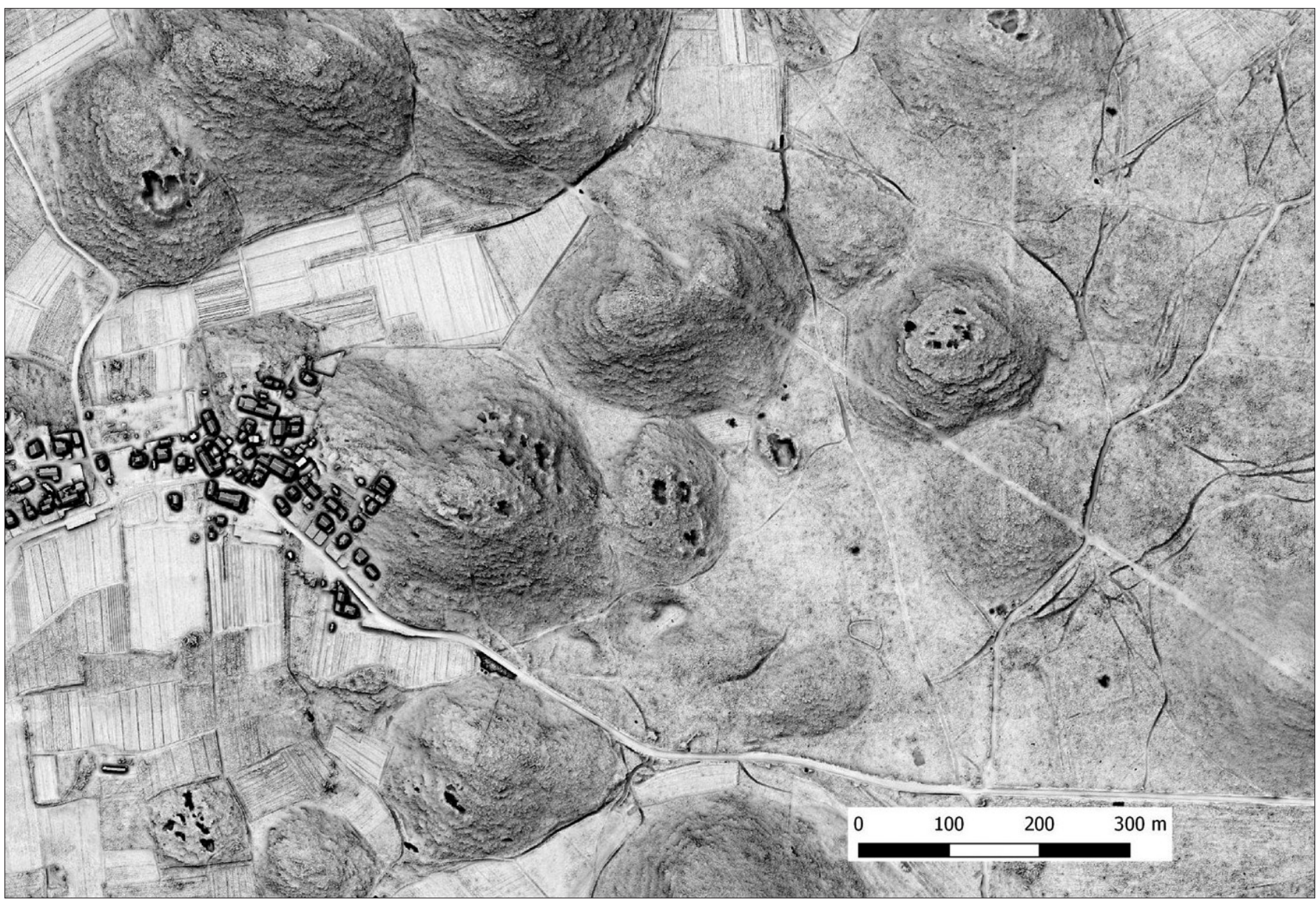

Figure 6. Negative features seen in the landscape on a LiDAR visualization, Vrsar municipality (made by: Katarina Šprem).

Šonje believed that a monolithic block from which the dome of Theodorik's Mausoleum in Ravenna was made had been extracted from this quarry (Šonje 1980: 153). Benčić mentions two other Roman quarries in the vicinity of Poreč - Naftaplin beach on the coast (Fig. 2: 30), and S. Angelo (Fig. 2: 31) less than 3 kilometres in the hinterland, where the remains of an unfinished Roman sarcophagus can be seen today (Benčić 2019: 115). Quarries at Vabriga and Tarska vala near Poreč (Fig 2: 24, 25) do not show any signs of Roman exploitation today. However, that may be so due to the proximity of the sea, which is conducive to the transportation of extracted stone and continuous exploitation. Furthermore, the proximity of Poreč could result in traces of Roman exploitation being lost due to modern exploitation for the need of construction works in the modern town. Tarska vala is the northernmost place on the western Istrian coast from which stone could be extracted for the needs of the northern coast (Matijašić 1998: 399).

\section{The case of LiDAR quarries}

A new technology developed in recent decades gave us the ability to detect quarries that have been otherwise overgrown in vegetation and therefore hard to spot in aerial photographs or during field surveys: Airborne Laser Scanning (ALS) or LiDAR. The whole area of the municipality of Vrsar was laser-scanned in 2017, and different LiDAR visualizations enable us to spot negative features which more often than not turn out to be quarries (Fig. 6). As a part of the ArchaeoCulTour project ${ }^{3}$, several negative features were selected for a targeted field survey (Fig. 11).

\footnotetext{
${ }^{3}$ Full name The Archaeological Landscape in a Sustainable Development of Cultural Tourism in the Municipality of Vrsar, HRZZPAR-2017-02-1; https://ffpu.unipu.hr/cirla/projekti/archaeocultour.
} 


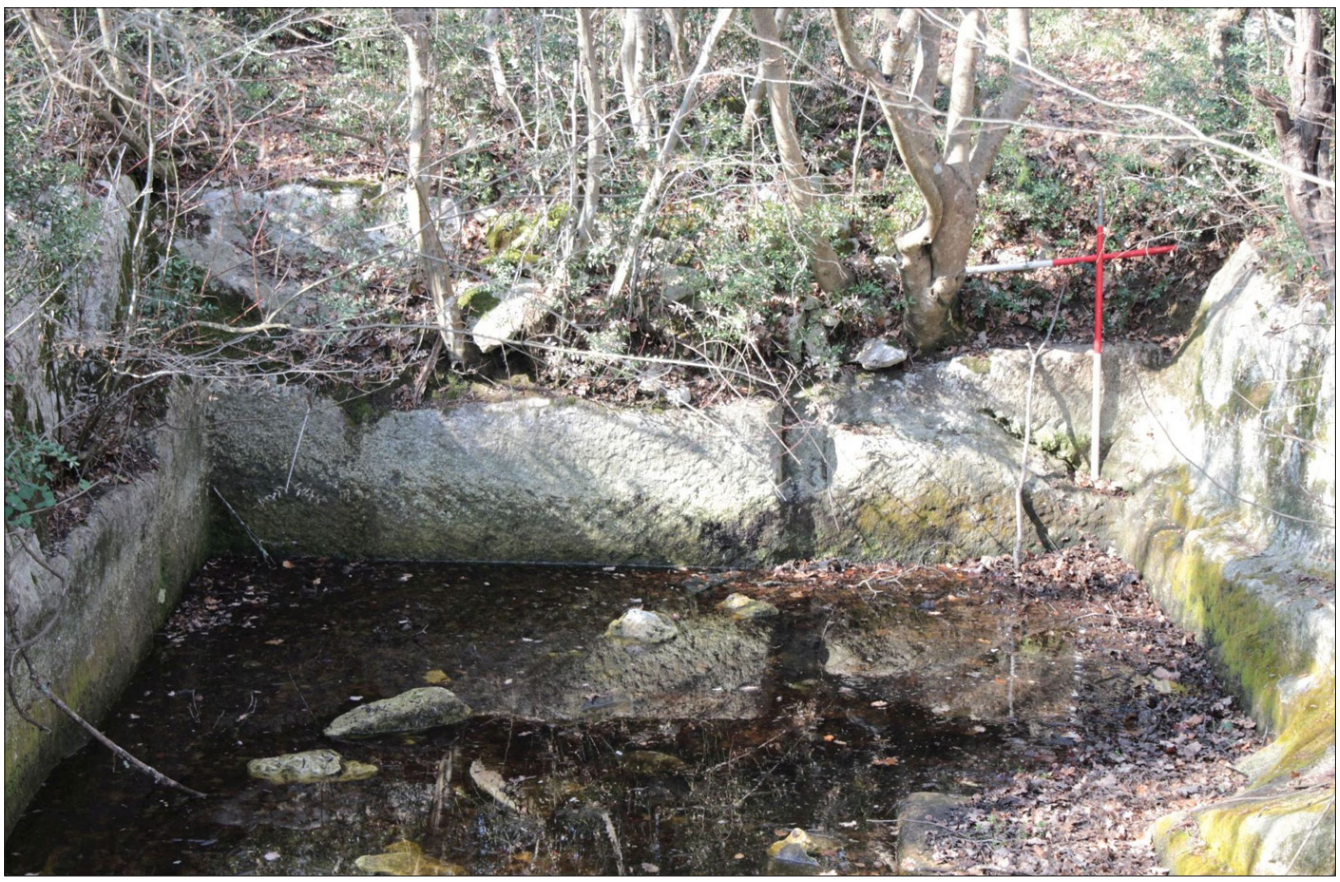

Figure 7. Traces of striae visible on a quarry face in a quarry near the village of Fleng (photo by: Robert Matijašić).

Thus, an abandoned quarry near Flengi village was spotted and surveyed (Fig 2: 36). No traces of modern stone extraction tools were observed and one of the quarry's faces displayed traces of striae associated with the usage of the two-spiked hammers (Fig. 7). A quarry of similar characteristics, but of much larger dimensions was surveyed on a hill called Biškupovi vrhi in Vrsar municipality (Fig. 2: 29). The quarry exhibits striae on one of its faces as well as at least four visible pašarini around 18 to $20 \mathrm{~cm}$ wide (Fig. 8). The width of pašarini in Roman quarries in Dalmatia, Croatia, is mostly around $20 \mathrm{~cm}$, up to the maximum width of $60 \mathrm{~cm}$. The wider pašarini were conditioned by a man's breadth and were thusly intended for a greater excavation depth and work within the pašarini themselves (Parica 2014: 137).

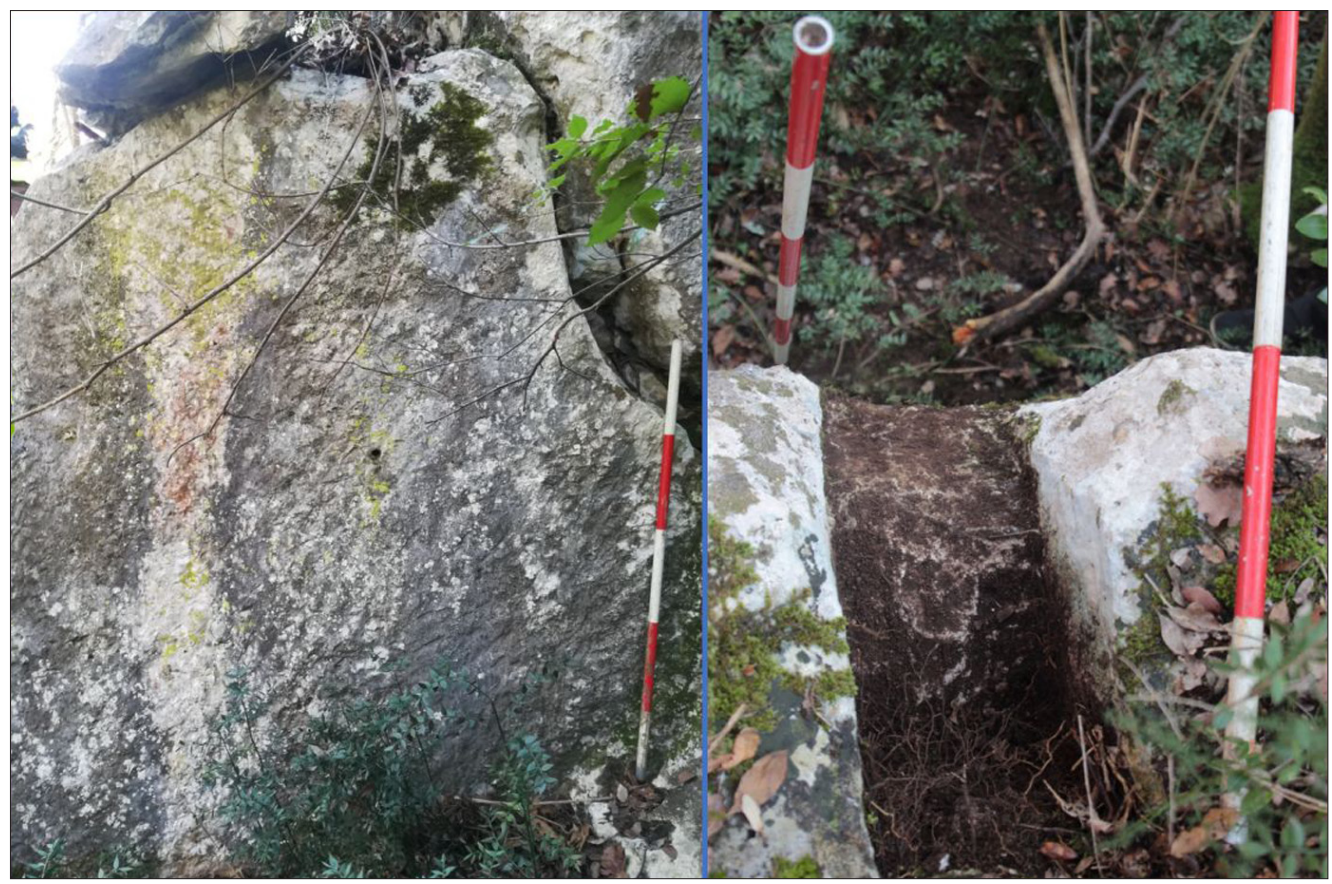

Figure 8. Traces of striae and a pašarin in a quarry on the Biškupovi vrhi hill (photo by: Katarina Šprem and Robert Matijašić). 
Figure 9. A second quarry on the Biškupovi vrhi hill (photo by: Katarina Šprem).

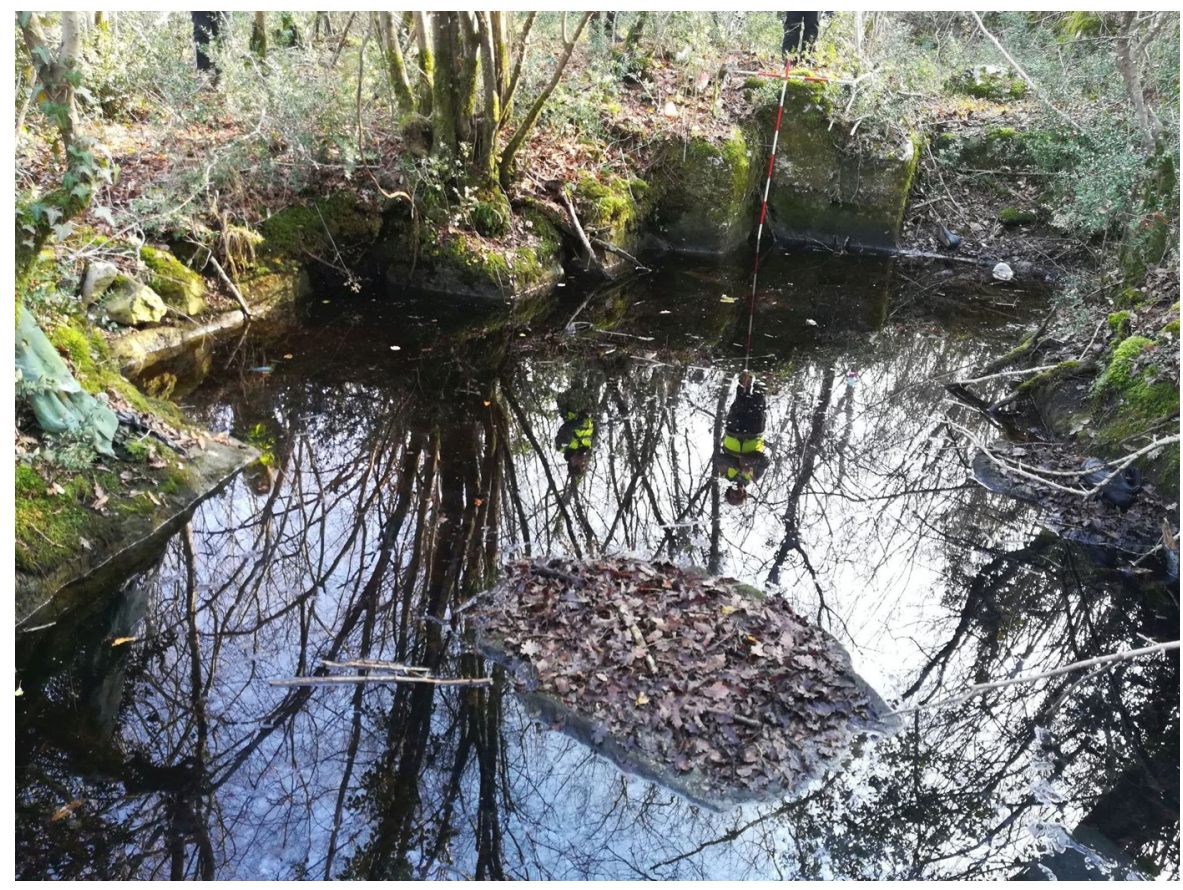

The other quarry also located on Biškupovi vrhi was partly submerged in freshwater, so no striae were visible at the time of the survey, but its rectangular layout could point to Roman usage (Fig. 9).
Several quarries between the villages of Flengi and Delići in Vrsar municipality also exhibit traces of striae and pašarini with the width of around $20 \mathrm{~cm}$, and they possess a rectangular layout (Fig. 2: 32, 37, 38; Fig 10.). However, a more detailed look should be undertaken.

Figure 10. Striae on a quarry face and a pašarin visible on two quarries in the vicinity of the village Flengi (photo by: Katarina Gerometta).

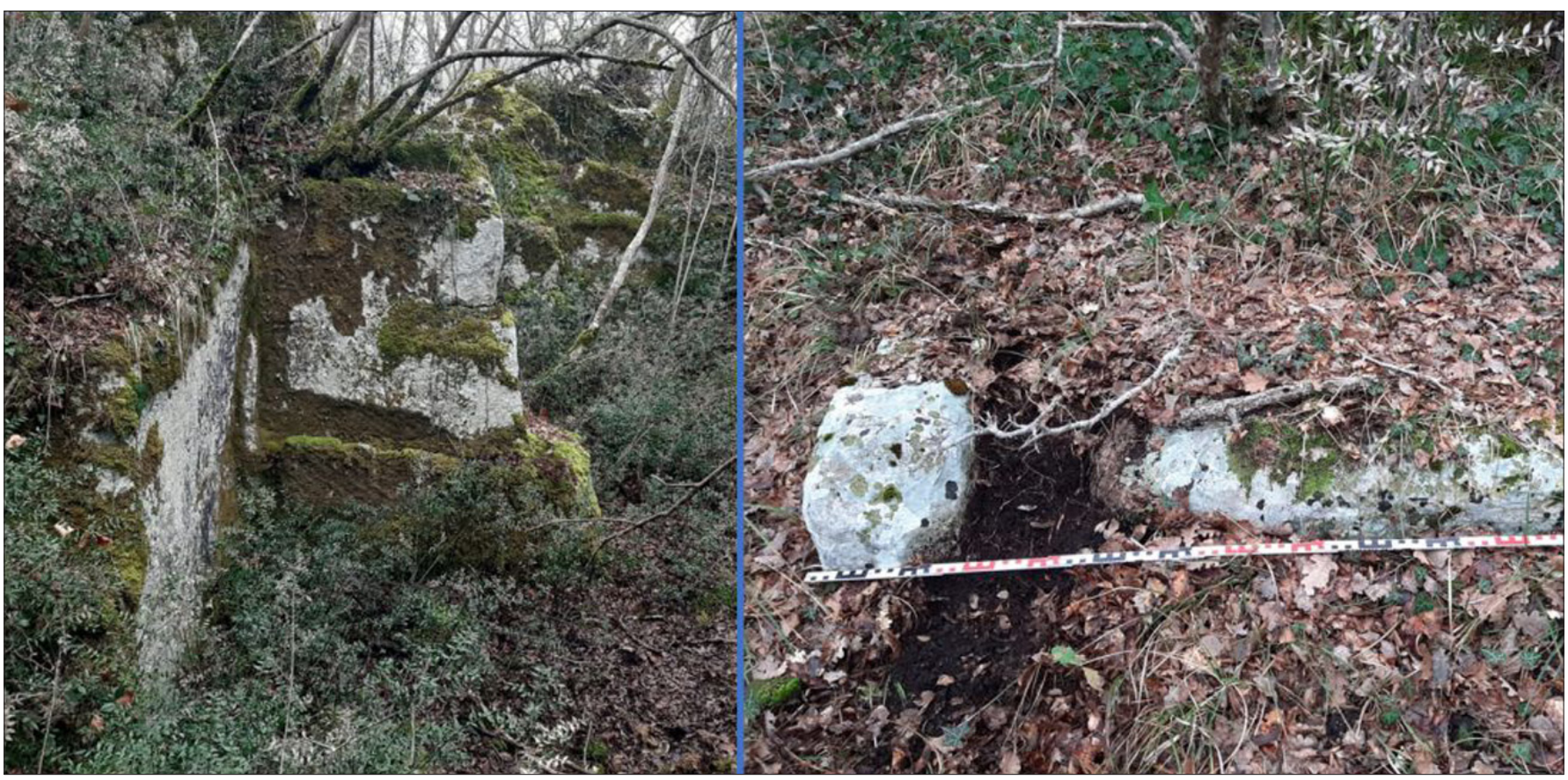




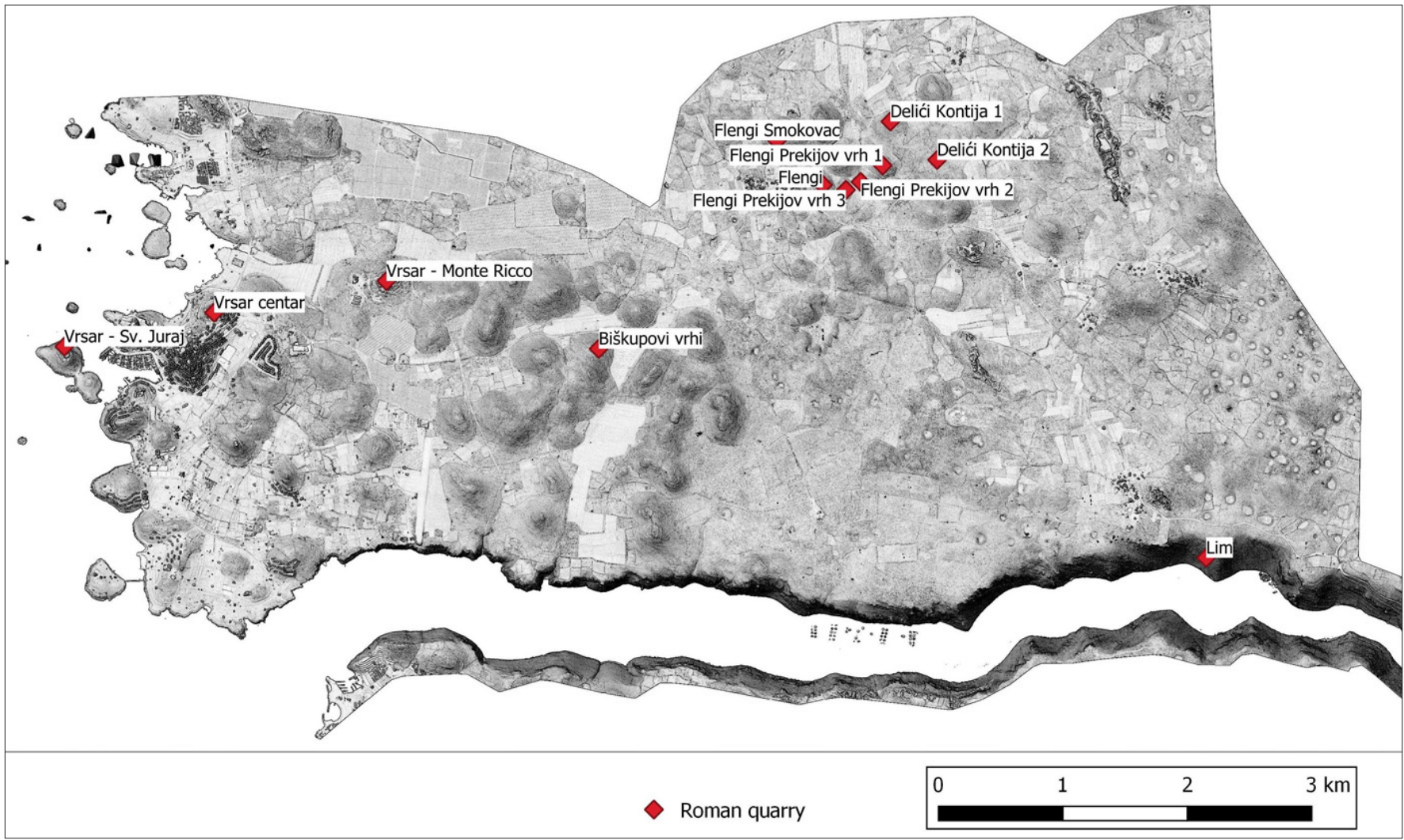

Figure 11. Probable Roman Age quarries in Vrsar municipality; several of them have been discovered using Airborne Laser Scanning data (made by: Katarina Šprem).

\section{Transport in Roman Istria}

Istria's transport system is conditioned by its geographical location and the natural features of the terrain and waters. Istria is surrounded on two sides by the sea, while in the north it is separated by Ćićarija, which is easiest to cross in only two or three places (Matijašić 1998: 417-418). Also, marshy valleys and river flows in northern Istria are obstacles to the establishment of road routes. The southern part of the Istrian peninsula is more easily manageable since the relief is flatter and without river flows (Matijašić 1998: 418). Roman roads often followed the routes of prehistoric paths that connected the most important settlements (Matijašić 2009: 197). However, the Istrian road network was probably established immediately after the colonization of the peninsula during Augustus' reign (Matijašić 1998: 419). The control of a conquered area is exercised through the establishment of military checkpoints that must be physically connected, and therefore roads were built and arranged that could be operated more quickly and safely (Matijašić 2009: 195). Although roads were being built for more efficient military management of space, civilian traffic was also moving through them. In this way, road construction technology has contributed to the progress of society (Matijašić 2009: 196). Nonetheless, roads in coastal areas were an alternative to maritime transport and were used mainly in the winter season when less navigation was possible (Matijašić 2009: 200).

From the fragment of Diocletian's Price Edict (Edictum De Pretiis Rerum Venalium) found in Aphrodisias in Caria, the price ratios of different modes of transport can be estimated. Thus, the ratio of the sea to the river downstream to the river upstream to land transport costs of 1: 3,9: 7,7: 42 was extrapolated (Russell 2014: 95), which explains why the focus of Roman politics was on maritime transport (Matijašić 1998: 419). The indented western coast of Istria was very important for traffic; this coast was connected to the surrounding areas already in prehistoric times by maritime trade, but also by looting and pirating (Gabrovec and Mihovilić 1987: 322-324). Every little bay from Medulin in the south to Savudrija in the north could have provided anchorage and shelter 
for ships and later had an even larger economic impact due to the import and export of various products. On the other hand, the eastern coast of Istria, Liburnian, was steep and inaccessible (Matijašić 1998: 419). In any case, navigation itself depended on weather and seasonality, as well as economic and other needs. The short-distance navigation along the coast was especially developed, and this type of navigation almost completely replaced land transport. The main navigable route ran between the larger islands and the mainland so that the vessels were protected from the high seas, and again close enough to a cove to take shelter when needed (Matijašić 2009: 201).

\section{Roman ports and docks}

The term "port" refers to a naturally or artificially protected sea, lake or river basin where ships can find shelter from waves, currents, tides and ice, where they can load, land or tranship cargo, food and water, make repairs and where the crew can rest (Koncani Uhač 2018: 65). There was a very extensive network of ports along the eastern Adriatic coast where ships could dock, and goods could be transhipped. In addition to the larger cities, which all had ports, smaller settlements, as well as individual villae rusticae or groups of villas, had their own port. Municipii also had ports (Matijašić 2009: 201).
Figure 12. Roman ports and bays which could have been used without the need for port facilities (made by: Katarina Šprem).

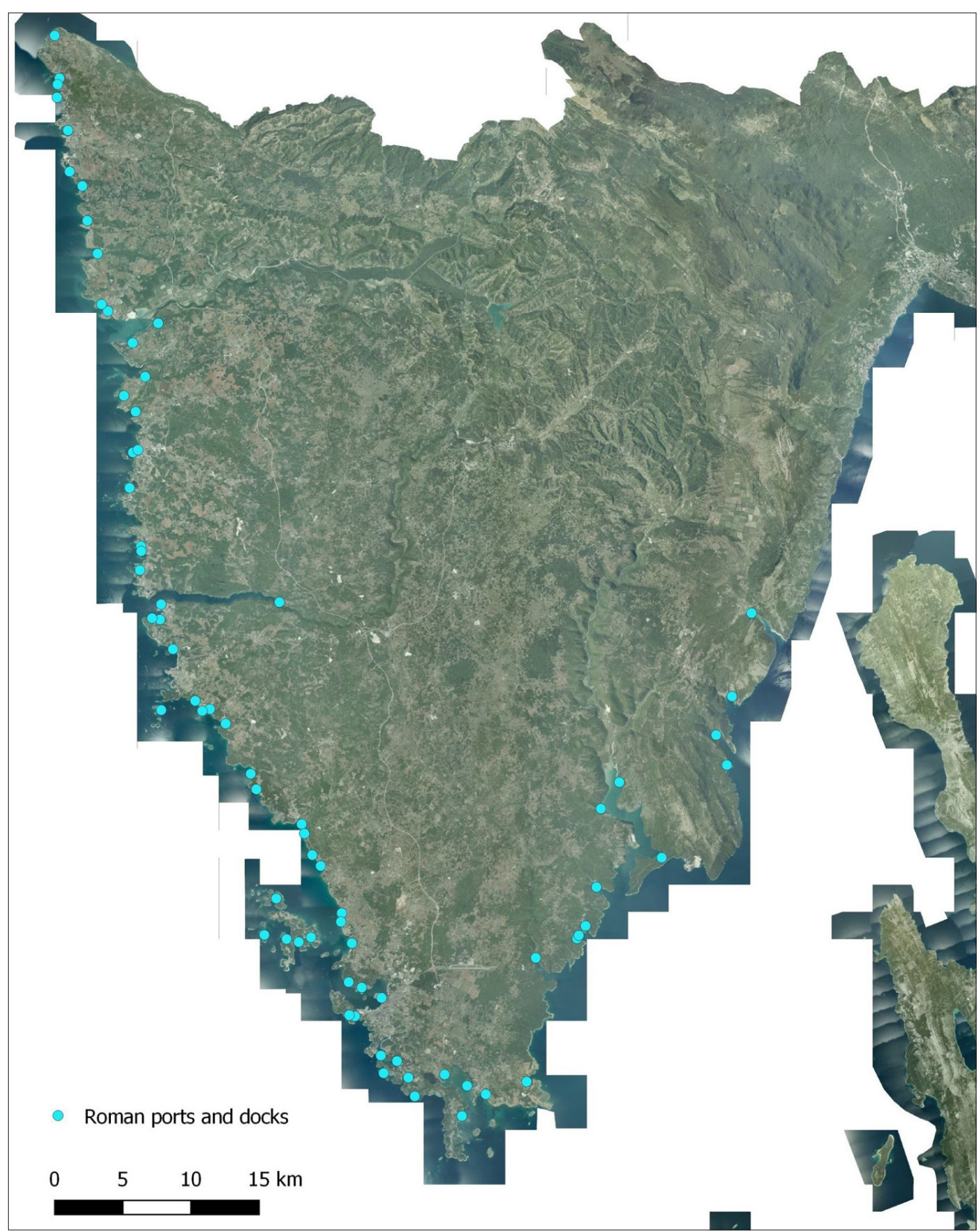


The dense rural settlements around the colonial cities also had access to the sea. There are many examples of such settlements in Istria (Matijašić 2009: 202). Archaeological excavations of such ports show they are mostly dated to the $1^{\text {st }}$ century when they were built as parts of residential and rural buildings (Koncani Uhač 2018: 141). However, some examples of natural anchorages and bays on the Istrian coast that were used in the Roman period show traces of use in prehistory (Mihovilić 1997) as well as Late Antiquity and the early Middle Ages (Brusić 1980; 2010), even until today.

Ports on the Istrian coast were densely distributed in Roman times (Fig. 12) and they can be divided into several groups (Koncani Uhač 2018: 143-145). According to the method of construction, they can be divided into natural ports - naturally protected bays which, by their morphology, enabled the safe anchoring of ships in case of bad weather or rest during navigation, and artificial ports bays that were adapted for the protection of ships (Koncani Uhač 2018: 144-145).

Marie-Brigite Carre and Francis Tassaux divided the ancient ports of Istria according to their size and importance in relation to economic context (Carre and Tassaux 2009: 65-78). Thus, the Roman ports can be divided into main (colonial) ports, secondary ports (municipal ports and agglomerations of settlements), ports of individual villae rusticae and ports related to individual production complexes (commercial ports) (Carre and Tassaux 2009: 69). Despite this division, some examples of ports on the Istrian coast cannot be attributed solely to one type of port, as their purpose can be multiple. The major ports on the Istrian coast had the function of city ports that belonged to political and territorial centres or colonies. Such ports include the colonial port of Tergeste, as well as the ports of Pola and Parentium, and the ports of the Late Antique urban settlements Ruginium (Rovinj), Humago (Umag) and Silbio (Savudrija) (Koncani Uhač 2018: 148). Through these main ports products from various Mediterranean regions were imported to Istria (Koncani Uhač 2018: 145-148). Secondary ports, on the other hand, are side ports to which agglomerations of settlements or towns of municipal status gravitated. Through these ports, unobstructed loading and unloading of goods could be ensured towards rural villas in the hinterland. An example of such a port is the one in Budava Bay which was used by municipium Nesactium (Vizače). Also, the ports of the Flanona (Plomin) and Alvona (Labin) could be classified as secondary ports (Koncani Uhač 2018: 148).
Almost every villa maritima in Istria had a port, and the majority of the total number of ports in Istria belongs to this category (Fig. 13). Through these ports, local products were concentrated towards a larger export port, either secondary or major (Koncani Uhač 2018: 151). They had observation posts that served to control sailing routes, and as such also served as landmarks on the coast. While villae maritimae had a pronounced economic component during the early Empire, their purpose became more defensive during the late Empire (Begović and Schrunk 2012: 327-344). Like maritime villa ports, commercial ports were also used for loading and unloading of certain commercial products. The main economic activity of Roman Istria was the production of olive oil or wine, while other important products were stone, lime, timber, fish products and others (Koncani Uhač 2018: 162-166).

\section{Land routes in Roman Istria}

As mentioned before, after the conquest of a certain territory, the Romans set up military checkpoints through which they observed and intervened in case of need. To better connect these checkpoints, roads were built to make travelling between them faster and safer (Fig. 15; Matijašić 2009: 195). The quality of the roads built was largely dependent on their military and economic importance, and the Romans built them in all areas they conquered. Traffic routes linking major urban settlements and other centres outside of Istria are known only

Figure 13. Percentage of ports in Istria according to their size and importance in relation to economic context (made by: Katarina Šprem, after: Koncani Uhač 2018).

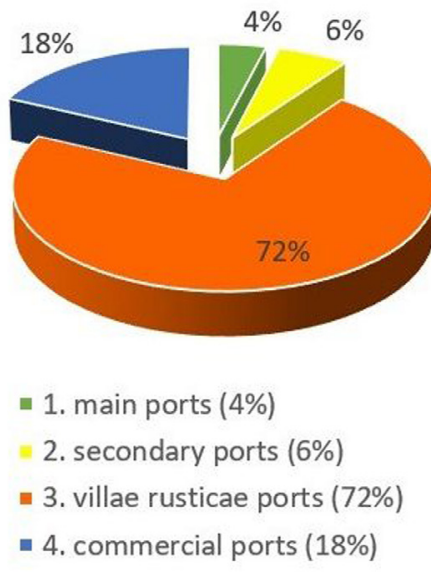


in their basic directions (Fig. 14). Our knowledge of the Roman roads network depends largely on the accidental findings of road tracks (Matijašić 1998: 420).

The western part of the road that connected Aquileia with Pola was called Via Flavia. Two milestones of the mentioned roads from the times of Vespasian were found in Pula and Vodnjan (Matijašić 1998: 421). It is also possible that a longer coastal road was used to support the maritime route along the western coast of Istria. In the Late Antiquity, settlements like Sapparis (Sipar), Humagum (Umag) and Neapolis (Novigrad) were formed along this side road (Matijašić 1998: 424). Smaller roads probably connected Poreč and Červar, as well as Poreč with Vrsar. South of the Lim Bay Barbariga was probably connected to the Rovinj area and with Pula (Matijašić 1998: 425). The road connecting Pula with Rijeka is also referred to by some authors as Via Flavia, some consider it an extension, but there is no confirmation for this. The road went from Pula through the Double Gate and continued in almost a straight line to Nesactium. One branch probably descended from Nesactium to Budava Bay. The road could have gone from Nesactium to Barban where it would cross Raša bay (Matijašić 1998: 426) or a shorter route through Mutvoran to Raša bay where it would cross the sea to Trget (latin Traiectum?) (Bosio 1991: 214). The road then con-

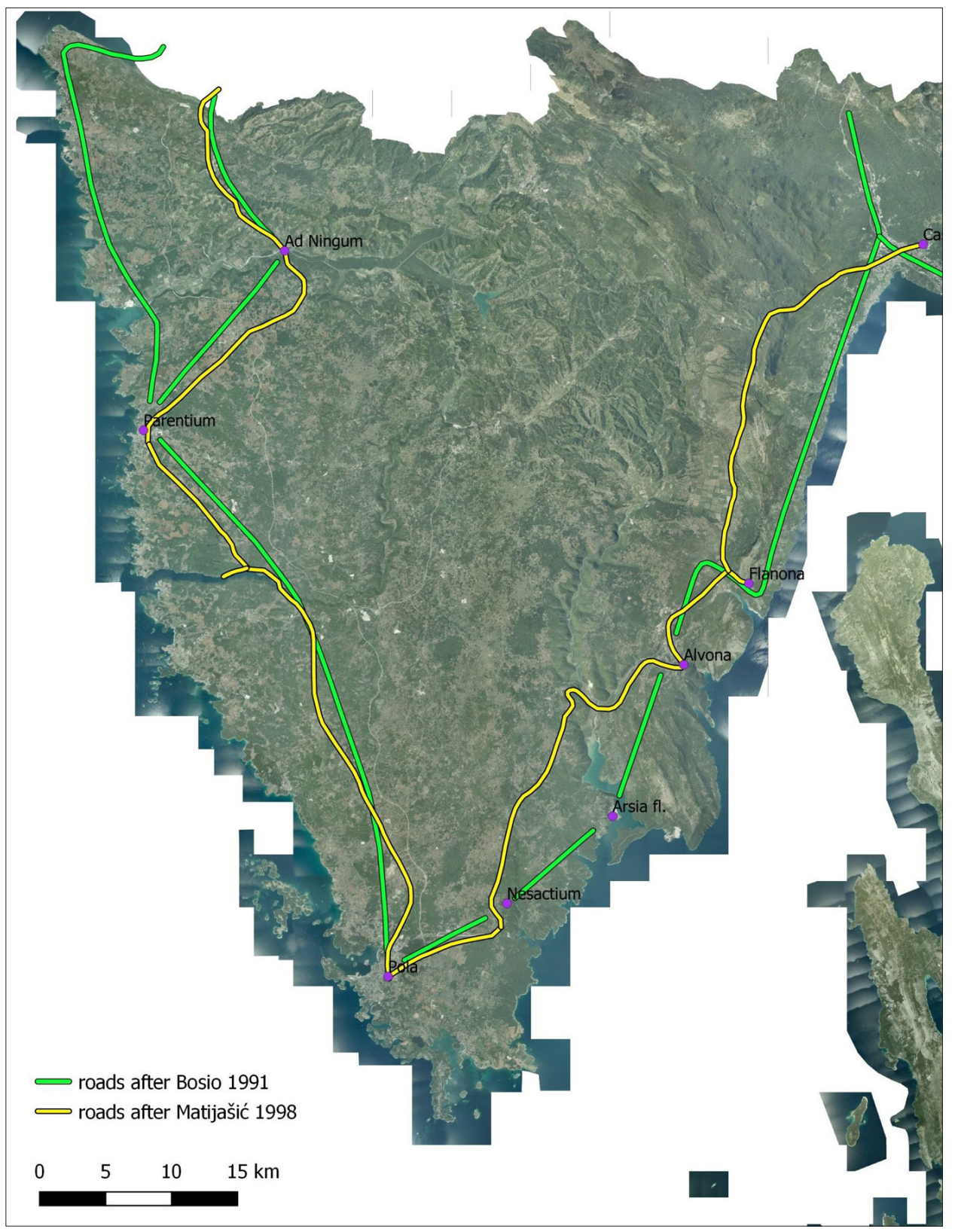

Figure 14. General direction of the Roman roads after Bosio (1991) and Matijašić (1998) (made by: Katarina Šprem). 


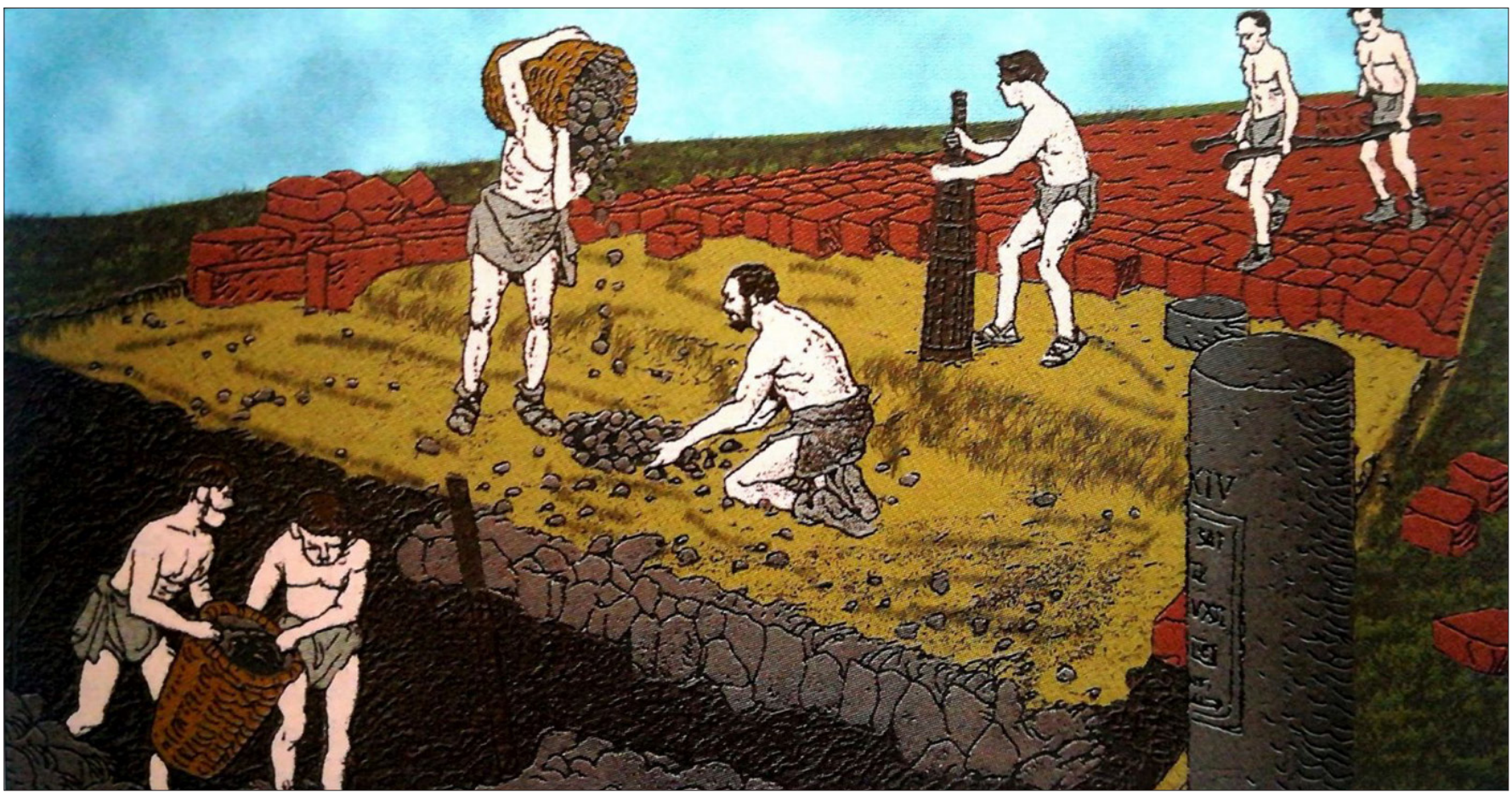

Figure 15. Road construction at different stages (after Goldstein 2007:371).

nected Liburnian municipalities in Labin and Plomin (Alvona and Flanona) and through them reached Tarsatica (present-day Rijeka). From Flanona the road to Tarsatica may have gone along the coasts of Liburnia (Bosio 1991) or through the interior of Istria west of Učka (Matijašić 1998: 424). On the other side of Učka mountain, the road went down to Matulji and Kastav (Castra) (Matijašić 1998: 425-426). It is unlikely that the road stretched along the coast of Liburnia, as Bosio assumes since the eastern Istrian coast is inaccessible and steep (Matijašić 1998: 426). Nevertheless, Mlakar also suggests a similar direction for the road (Mlakar 1962).

\section{Discussion}

When it comes to the exploitation of stone, it is very important to keep in mind the link between the proximity of the source and the possibility of transportation, since there are huge differences in cost between land transport and sea transport (Matijašić 1998: 395; Russell 2014: 95). Considering the fact that the cheapest mode of transport was by a river or sea, the quarries from which stone blocks were extracted for wider distribution were most often located just near the mouth of the river or on the seashore (Russell 2014: 139). Furthermore, in the case of the Istrian peninsula, land transport was restricted to routes connecting the central parts to the west coast (Matijašić 1998: 292). If we take a look at the Dalmatian islands and their large number of Roman quarries, we can ascertain that there is a certain connection between the convenient location for cheap and cost-effective transportation of stone and the selection of places for extracting the high-quality stone (Parica 2012: 345-346). Of course, the primary reason for opening the quarry remains the quality of the stone itself.

In addition to commercial ports related to the loading and unloading of certain commercial products, villae maritimae ports also had economic importance. Villae maritime could have also had, besides residential quarters, economic facilities, while their port facilities covered the trade from the hinterland - through these ports, local products were concentrated towards a larger export port, either major or secondary. These local products were associated with a specific activity in the microregional area (Koncani Uhač 2018: 151); one of these activities could have also been stonemasonry and exploitation of stone from quarries. However, the location of the 
ports in the immediate vicinity of the quarries does not need to be an indication of their function as ports for loading stone from the quarries. Smaller quarries along the coast could have been used to build a nearby villa with a pier, and not necessarily for wider distribution. On the other hand, stone blocks extracted from these quarries could have easily been directly loaded onto a ship without the need for port facilities (Koncani Uhač 2018: 168). Likewise, bays could have been used for anchoring without the need for a port facility (Koncani Uhač 2018: 144).
Nevertheless, most Roman quarries in Istria have one or more Roman ports or docks within a two-kilometre radius (Fig. 16). The exception to this are the quarries in the interior of the peninsula: Šandalja - San Daniele, Marčana, Bale - Skačota, Lim, S. Angelo and a number of small quarries near the villages of Flengi and Delići in $\mathrm{Vr}$ sar municipality. Stone blocks from these quarries could have been used to build the surrounding villae rusticae, and if it was of high-quality, it could have been transported by land to the nearest port. All the afore-mentioned quarries, except the two on Biškupovi vrhi, are around

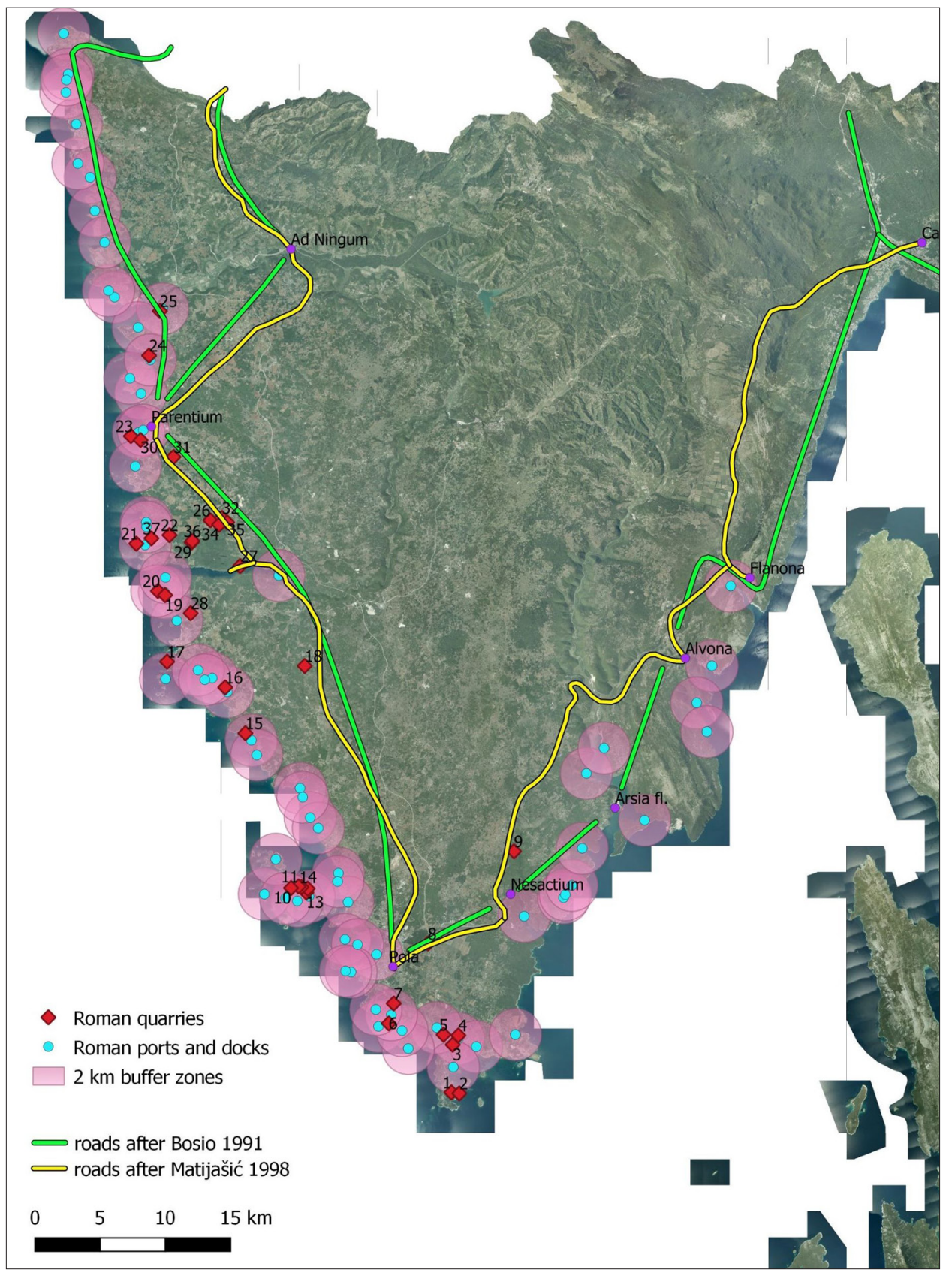

Figure 16. Supposed stretch of the Roman road, locations of the Roman ports and docks, and Roman quarries (made by: Katarina Šprem). 
$1 \mathrm{~km}$ from the supposed stretch of the Roman road. As for the nearest ports, for the quarry in Šandalja, it is Pula's main port, for Marčana quarry the nearest port is in Budava Bay, for the Bale-Skačota quarry it would be the ports in Vištar Bay or St. Paul near Rovinj. Stone blocks from the quarry on the slopes of the Lim Bay could have been directly loaded onto a ship a few meters lower. Stone blocks from $\mathrm{S}$. Angelo quarry could have been transported by roads to the port in Mulandrija Bay or the main port of Parentium, both of which are some 3 km away.

The analysis of Airborne Laser Scanning images, which through different visualisations enables us to detect quarries overgrown in vegetation, also allows us to observe a different kind of negative features - the so-called holloways. According to Mlekuž, holloways are "material traces of past movement, a movement that is being materialised in the form of traces left in the soil" (Mlekuž 2013: 37). Holloways are not built but are eroded due to the constant flow of people, animals or carts. Eventually, they become water conduits as well, which erodes these lanes even further. Then, some alternative routes are taken by people, which leads to the formation of "river-like braided channels" (Mlekuž 2013: 38; see also Edgeworth 2011). These holloways can also be seen in the landscape of Vrsar municipality (Fig. 17). They can be seen branching close to all the quarries so far surveyed in the municipality which suggests human movement around these sites.

Figure 17. Holloways seen reaching out to the quarries in the vicinity of Flengi and Delići, Vrsar municipality (made by: Katarina Šprem).

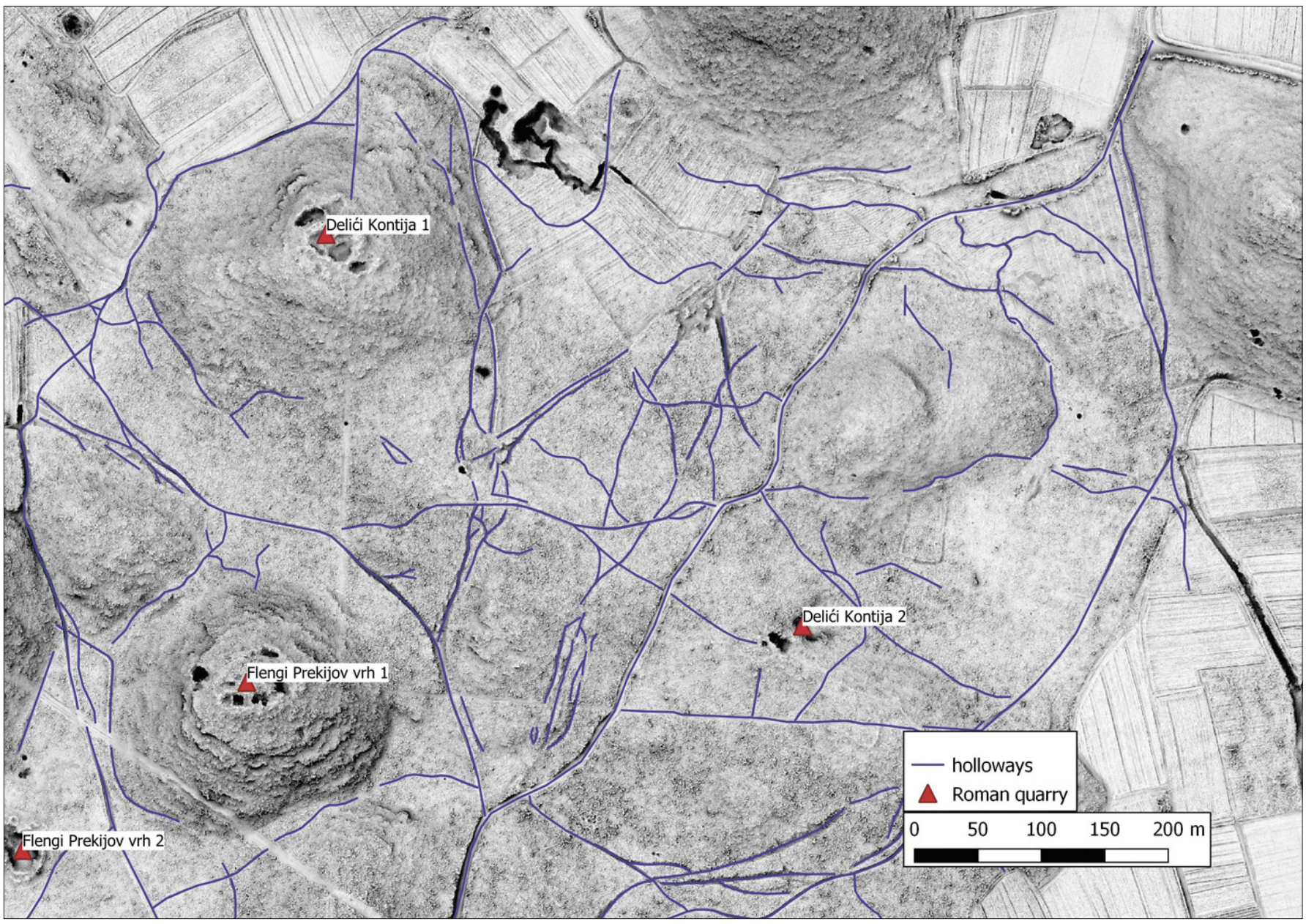




\section{Conclusion}

Istria is rich in surface deposits of high-quality limestone. Romans were also aware of said quality and exploited the stone from several positions on the peninsula. Some of the Roman quarries have been mentioned in the bibliography of the last decades (e.g. Šonje and Matijašić), while new technologies in archaeology help to discover quarries that are overgrown in vegetation and therefore hard to spot. Such is the case with quarries in Vrsar municipality, e.g. Flengi, Delići and Biškupovi vrhi which were only discovered using the Airborne Laser Scanning technique. On the other hand, the possibility of transporting the extracted stone blocks is an essential element of raw material exploitation. Maritime and river transport is cheaper compared to inland transport that is a more expensive and time-consuming option. The Istrian coastline is richly indented and offers a large number of bays suitable for anchoring, most of them close to the remains of Roman villae rusticae where seafarers could load, unload or reload their goods or rest a while. The western Istrian coast allows for the so-called longdistance cabotage, meaning sailing on shorter routes with stops in smaller ports. Quarries that were probably exploited in Antiquity are mostly located on the coastline or near the supposed direction of ancient roads. Their location allowed for faster and more efficient distribution.

The presented data is a valuable start to the study of the Roman exploitation of Istrian stone raw material. Further analyses - like petrographic or even geochemical - can provide us with information on the distribution of the extracted blocks. The question worth asking is whether a particular quarry was used for the needs of the inhabitants of the Istrian peninsula, or it was sought over greater distances because of its quality (as Šonje suggested for the building of Theodorik's Mausoleum). In any case, the issue of the use and distribution of Istrian limestone in ancient times must be approached with more analyses in mind, and certainly with caution.

\section{Acknowledgements}

ArchaeoCulTour project (HRZZ-PAR-2017-02-1) is financed by the Croatian Science Foundation, Vrsar Municipality, Vrsar Tourist Board and Maistra d.d. Rovinj and the doctoral position of Katarina Šprem at the Juraj Dobrila University of Pula is financed by the European Social Fund and the Croatian Science Foundation (ESF-DOK-01-2018). 


\section{References}

Begović, V. and Schrunk, I. 2012. The role of maritime villas in seafaring in the Adriatic, Histria Antiqua 21, 327-344.

Benčić, G. 2019. Notte sulla lavorazione ed esportazione della pietra d'Istria nel medioevo, In: M. Mogorović Crljenko and E. Uljančić (eds.), Artisani et mercatores...: Artisans and Merchants in the Adriatic Area, Collected Papers from the International Scientific Conference, Vol. 8, 100-117.

Bosio, L. 1991. Le strade romane della Venetia e dell'Histria, Studio Editoriale Programma, Padova.

Brusić, Z. 1980. Neki oblici kasnoantičke keramike s podmorskih nalazišta uz našu obalu, In: I. Erceg, A. Horvat, I. Mažuran and M. Suić (eds.), Gunjačin zbornik, 77-86.

Brusić, Z. 2010. Ranosrednjovjekovni nalazi iz hrvatskog podmorja, Archaeologia Adriatica 4, 243-255.

Bulić, D. 2014. Rimska ruralna arhitektura Istre u kontekstu ekonomske i socijalne povijesti, University of Zadar, unpublished PhD dissertation.

Buršić-Matijašić, K. and Matijašić, R. 2016. Projekt RATROPH i arheološko istraživanje u Vrsaru 2014. i 2015. God, Obavijesti Hrvatskog arheološkog društva XLVIII, 17-25.

Bratulić, J. and Cotman, I. 2004. Kamen Pazin. A volume devoted to 50th anniversary, 1954 - 2004., Kamen Pazin, Pazin.

Carre, M.-B. and Tassaux, F. 2009. L'Istrie et la navigation nord-adriatique dans l'antiquité romaine, Histria Antiqua 17, 65-78.

Crnković, B. 1991. The Origin of the Dimension Stone of the Arena in Pula, Rudarsko-geološko-naftni zbornik 3, 6367.

Džin, K. and Miholjek, I. 2016. Konzervatorski elaborat za arheološke lokalitete Vižula i Burle, Medulin.

Edgeworth, M. 2011. Fluid Pasts: Archaeology of Flow, Bristol Classical Press, London.

Gabrovec, S. and Mihovilić, K. 1987. Istarska grupa, In: A. Benac (ed.), Praistorija jugoslavenskih zemalja 5, Sarajevo, 293-338.

Goldstein, I. 2007. (ed.). Povijest 4. Rimsko Carstvo, Europapress holding, Zagreb.

Koncani Uhač, I. 2018. Rimski lučki uređaji u Istri i njihov arheološki kontekst (Roman port installations in Istria and their archaeological context, summary), University of Zadar, unpublished PhD dissertation.

Koncani Uhač, I., Auriemma, R., Gaddi, D., Alfonso, C., Dell'Anna, A. and Furlani, S. 2012. Savudrijski zaljev: luka i priobalje u rimsko doba, Histria Antiqua 21, 571-579.
Kozličić, M. 1990. Historijska geografija istočnog Jadrana u starom vijeku, Književni krug Split, Split.

Lazzarini, L. 2012. Pietra d'Istria: Quarries, characterisation, deterioration of the stone of Venice, In: $12^{\text {th }}$ International Congress on the Deterioration and Conservation of Stone, Columbia University, New York.

Matijašić, R. 1988. Ageri antičkih kolonija Pola i Parentium i njihova naseljenost od I. do III. Stoljeća, Latina et Graeca - VPA, Zagreb.

Matijašić, R. 1998. Gospodarstvo antičke Istre, Zavičajna naklada „Žakan Juri“ Pula, Pula.

Matijašić, R. 2009. Povijest hrvatskih zemalja u antici do cara Dioklecijana, Leykam International, Zagreb.

Matijašić, R. 2017. Romanization of the Histri in the Early Roman Period, In: D. Demicheli (ed.), Illyrica Antiqua in Honorem Duje Rendić-Miočević, Proceedings of the International Conference, Šibenik, 12th-15th September 2013, Zagreb, 379-390.

Mihovilić, K. 1997. Školjić (Funtana) i tragovi prapovijesnih obalnih i otočnih lokaliteta Istre, Histria Archaeologica 26, 28-57.

Miko, S., Kruk, B., Dedić, Ž., Kruk, L., Peh, Z., KovačevićGalović, E. and Gabrić, A. 2013. Rudarsko-geološka studija potencijala i gospodarenja mineralnim sirovinama Istarske županije, Hrvatski geološki institut, Zagreb.

Mlakar, Š. 1962. Istra u antici, Tiskara Otokar Keršovani, Pula.

Mlekuž, D. 2013. Roads to nowhere? Disentangling meshworks of holloways, In: Z. Czajlik and A. Bödőcs (eds.), Aerial Archaeology and Remote Sensing from the Baltic to the Adriatic, Selected Papers of the Annual Conference of the Aerial Archaeology Research Group, $13^{\text {th }}-15^{\text {th }}$ September 2012, Budapest, Hungary.

Parica, M. 2012. Nekoliko primjera lučkih instalacija antičkih kamenoloma na dalmatinskim otocima (Some Examples of Harbour Installations of Ancient Quarries on the Dalmatian Islands, summary), Histria antiqua 21, 345-355.

Parica, M. 2014. Tool traces in the Classical Antiquity and Mediaeval quarries of Dalmatia as an aid in the chronological definition of individual stages of exploitation, $\mathrm{Ar}$ chaeologia Adriatica VIII, 51-80.

Parica, M. 2014a. Arheološki tragovi kamenarstva u Dalmaciji od prapovijesti do kraja srednjeg vijeka (Archaeological evidence of stone quarrying in Dalmatia from prehistory to the end of the Middle Ages, summary), University of Zagreb, unpublished PhD dissertation. 
Premužić Ančić, M. and Gašparović, S. 2017. Quarries on the island Veliki Brijun. The Beginnings of their rehabilitation and adaptive reuse in Croatia, A Scholarly Journal of Architecture and Urban Planning 25, 74-85.

Russell, B. 2014. The Economics of the Roman Stone Trade, Oxford University Press, Oxford.
Šonje, A. 1980. Iz kojeg istarskog kamena potječe kupola Teodorikova mauzoleja u Ravenni. In: M. Suić and M. Zaninović (eds.), Materijali, tehnike i structure, Odjel za arheologiju, Centar za povijesne znanosti, Zagreb, 149-160. 